\title{
The Reduction of the Permeability of a Lateritic Soil through the Application of Microbially Induced Calcite Precipitation
}

\author{
Anthony Smith', Martin Pritchard1, Alan Edmondson'², Shafakat Bashir1 \\ ${ }^{1}$ School of the Built Environment and Engineering, Leeds Beckett University, Leeds, UK \\ ${ }^{2}$ School of Clinical \& Applied Sciences, Leeds Beckett University, Leeds, UK \\ Email:a.o.smith@leedsbeckett.ac.uk,m.pritchard@leedsbeckett.ac.uk, a.edmondson@leedsbeckett.ac.uk, \\ shafakat.bashir16@imperial.ac.uk
}

How to cite this paper: Smith, A. Pritchard, M., Edmondson, A. and Bashir, S. (2017) The Reduction of the Permeability of a Lateritic Soil through the Application of Microbially Induced Calcite Precipitation. Natural Resources, 8, 337-352. https://doi.org/10.4236/nr.2017.85021

Received: March 29, 2017

Accepted: May 21, 2017

Published: May 26, 2017

Copyright $\odot 2017$ by authors and Scientific Research Publishing Inc. This work is licensed under the Creative Commons Attribution International License (CC BY 4.0).

http://creativecommons.org/licenses/by/4.0/

\begin{abstract}
Lateritic soils are frequently utilised in tropical areas of the developing world as an engineering material in the construction of rural earth roads, usually in the form of engineered natural surface (ENS) roads. The heavy, seasonal rainfalls common to the tropics results in ENS roads becoming quickly saturated with rainwater, and no longer accessible to motorised transportation. Microbially induced calcite precipitation (MICP) has been successfully used as a treatment process to decrease the permeability of clean, cohesionless sands by studies trying to impede the movement of groundwater, and any pollutants they may contain. In order to see if MICP treatment can also reduce the susceptibility of ENS road lateritic soils to rainwater saturation, this study has treated a Brazilian sample extracted from an ENS road in Espirito do Santo, Brazil, using the MICP bacterium Sporosarcina pasteurii contained within a urea-calcium chloride solution inoculum. Investigation, by means of a Rowe cell, of the post-treatment permeability, to untreated control samples, has shown an average decrease in the vertical coefficient of permeability of $83 \%$, from $1.15 \times 10^{-7} \mathrm{~m} / \mathrm{s}$ for the untreated control samples, to $1.92 \times 10^{-8} \mathrm{~m} / \mathrm{s}$ in treated samples.
\end{abstract}

\section{Keywords}

Microbially Induced Calcite Precipitation (MICP), Lateritic Soil, ENS Road, Permeability

\section{Introduction}

\subsection{Engineered Natural Surface Roads}

Rural road infrastructure improvement is contained within a number of the tar- 
gets defined under Goal 9 (Industry, Innovation and Infrastructure) of the 2030 sustainable development goals (SDGs), with expectations that it could increase local produce marketing and commerce [1]. The transport infrastructural needs of around $70 \%$ of the populations of International Development Association (IDA) countries are served by engineered natural surface (ENS) roads [2]; Brazil as an example possesses a road network containing $87 \%$ of unpaved roads [3]. They are formed by the compaction and shaping of the in situ surface soil [4]. It is very rare for ENS roads to be upgraded at a later time with a bitumen-based wearing surface [5].

Typically, in tropical areas the in situ soil material is lateritic clay, a residual soil formed from the local laterite geology. As a geological classification, laterite has proved difficult to define [6] ever since its first description by Buchanan (1807) [7]. Additionally, lateritic soils form over varying types of geologic material [8]. The most common clay mineral in lateritic soils is kaolinite, representing $80 \%-97 \%$ of the soil [9]. The soil is typically red or yellow due to oxides formed when exposed to atmospheric oxygen [10], with a silica-sesquioxide ratio of $<2$, where a ratio $<1.33$ is considered a "true laterite soil" [11]. A secondary characteristic of lateritic soil formation is alternating wet and dry seasons, a common feature of the tropics [9].

Indeed, it is these cyclical wet seasons, driven by the North-South migration of the intertropical convergence zone (ITCZ), which poses the biggest threat to lateritic ENS roads. When dry, the soil provides a hardy engineering material. However, when saturated by rainwater during a tropical wet season, it is weakened to such a degree that it leaves the road impassable to all mechanical transport; $85 \%$ of sub-Saharan roads become impassable during wet season rains [12].

Without dedicated governmental maintenance ENS roads remain unusable for long periods of time, leaving villagers struggling to access capital assets that should be readily available to them, namely: natural, social, financial, human and physical [13]. The impacts felt from wet seasons are expected to worsen with global climate change [14]. Sub-Saharan nations face a potential US \$500 million rise in road maintenance costs through 2050; the equivalent cost estimated to be US \$10.5 billion for South-East Asian countries [15] [16].

Microbially induced calcite precipitation (MICP) may provide a low-cost sustainable means by which lateritic soils can be protected from rainwater saturation. The costs of the raw materials involved in using chemical grouts typically applied to problematic soils, can range from US $\$ 2$ to US $\$ 72$ per $\cdot \mathrm{m}^{3}$ of soil, whereas the raw materials for MICP treatments range from US $\$ 0.5$ to US $\$ 9$ per $\cdot \mathrm{m}^{3}$. Where organic agricultural waste can be used as the carbon source, eight-fold cost savings are possible. MICP also provides a non-toxic alternative to the acrylamides, lignosulfonates and polyurethane additives typically found in classical soil treatment agents [17].

\subsection{MICP Using Sporosarcina pasteurii}

Sporosarcina pasteurii is a ubiquitous, naturally occurring soil bacterium [18] 
[19], formerly classified as Bacillus pasteurii [20]. It has a unique adenosine triphosphate (ATP) synthesis mechanism that is coupled to the hydrolysis of urea [21], a feat the bacterium can perform due to the possession of the hydrolysing enzyme, urease [22]. This hydrolysis results in the excretion of dissolved inorganic carbon $\left(\mathrm{CO}_{3}^{2-}\right)$ and ammonium ions $\left(\mathrm{NH}_{4}^{+}\right)$. Separately, calcium ions $\left(\mathrm{Ca}^{2+}\right)$ are adhered to the negatively charged cell membrane [23] allowing it to act as a nucleation site for the excreted $\mathrm{CO}_{3}^{2-}$ and the adhered $\mathrm{Ca}^{2+}$. This induces the precipitation of calcium carbonate $\left(\mathrm{CaCO}_{3}\right)$ calcite crystals around the bacterium. This calcite provides an agent for soil modification by acting as a "biocement".

Whiffin et al. [24] monitored changes to permeability in a five-metre sand column, which had post-treatment reductions in permeability ranging from $80 \%$ (down to $2 \times 10^{-5} \mathrm{~m} / \mathrm{s}$ ) in the first two metres of the column, to $40 \%$ (down to $6 \times$ $10^{-5} \mathrm{~m} / \mathrm{s}$ ) in the remaining three metres. Further direct permeability testing of sub-samples from the column, using a triaxial hydraulic cell, also showed slightly reduced permeability readings over the entire column. More importantly, this testing revealed that the level of reduction was constant within the column. It was observed that the calcite precipitation was not however uniform throughout the column, and therefore the reduction in permeability did not appear to be related to precipitated calcite content within the soil. The possible sources of reduction discussed included the nature of how each permeability sample was packed, or that perhaps calcite was present but that the evacuation techniques used to measure its presence were not sensitive enough to record it.

Stabnikov et al. [25] aimed to produce a water impermeable crust on a sand surface through the precipitation of calcite crystals into the pore-throats between sand particles. A strain of $S$. pasteurii was cultivated and $8 \mathrm{~g}$ of the bacterial mass was suspended in a $0.75 \mathrm{M} \mathrm{CaCl}_{2}$ solution at a $\mathrm{pH}$ of 7 . This solution was used to treat the surface of a model pond sand structure, and it was found that its permeability was reduced from $1 \times 10^{-4}$ to $1.6 \times 10^{-8} \mathrm{~m} / \mathrm{s}$. Unlike the previously reviewed papers, Stabnikov et al. [25] sought to establish the nature and quantity of calcite precipitation, in order to provide evidence of a link between MICP activity and permeability reduction. This was undertaken using scanning electron microscopy (SEM), which showed that the formation of $\mathrm{CaCO}_{3}$ crystals was occurring directly onto the surfaces of the treated sand grains, where bacterial cells or urea molecules had possibly acted as nucleation points. SEM imagery revealed that, while bacterial cell aggregation occurred naturally, the use of $\mathrm{CaCl}_{2}$ had a positive correlative effect upon the size of such aggregation. The average cell aggregation size imaged, when no $\mathrm{CaCl}_{2}$ had been administered, was $1 \mu \mathrm{m}$. Aggregation size increased on average to $10 \mu \mathrm{m}$ when $\mathrm{CaCl}_{2}$ was administered to the sand. However, it was noted that when $\mathrm{CaCl}_{2}$ was administered, cell aggregates of up to $400 \mu \mathrm{m}$ was observed in the top surface layers of the sand where they had been immobilised since their size prevented them from penetrating further into the pore system. It was found that these aggregations were those responsible for the observed formation of the water-impermeable crust on the surface of the MICP treated sand sample. 
Chu et al. [26] closely examined the effect of $\mathrm{Ca}^{2+}$ distribution on the resulting pattern of $\mathrm{CaCO}_{3}$ distribution in $1 \mathrm{~L}$ beakers of MICP treated sand. All beakers were fully treated with a bacterial solution for 1.5 hours, after which the solution was drained away and a $\mathrm{CaCl}_{2}$-urea solution was then added to the sand for a 12-hour period before the sand was drained once more. Half of the beakers were filled with enough $\mathrm{CaCl}_{2}$-urea solution so that the level rose to $20 \mathrm{~mm}$ above the top-most sand. The remaining beakers were filled without allowing the $\mathrm{CaCl}_{2}$ urea solution to reach the surface of the sand. As with Stabnikov et al. [25], it was observed that when the sand's top surface was immersed in the more aerobic $20 \mathrm{~mm}$ layer of $\mathrm{CaCl}_{2}$-urea solution, a crust of less-permeable sand formed. In the other samples, it was observed that calcite precipitation had been much more homogeneous in its distribution. The permeability of all samples was shown to have reduced to $1.6 \times 10^{-7} \mathrm{~m} / \mathrm{s}$, although no value of the sand's pre-treatment permeability was given, but can be compared with typical clean sand permeability values between $1 \times 10^{-2}$ and $1 \times 10^{-5} \mathrm{~m} / \mathrm{s}$ [27].

Omar et al. [28] demonstrated the sustainable nature of employing MICP as a means of soil modification. In this technique, as opposed to the usual cultivation of one specific strain of a ureolytic bacterium, a "vege-grout" was created through the fermentation of agricultural waste, using a mixture of vegetables containing Cucumissativus, Ipomoea aquatic and Vigna unguiculata sesquipedalis. The vege-grout was the liquid extracted from this fermented mass, and it contained typical soil bacteria, including Bacillus subtilis and S. pasteurii. $200 \mathrm{~g}$ samples of micaceous soil samples were extracted using a sampling tube from an area where a shallow landslide had occurred. These samples were broken down in order to mix in the vege-grout to $15 \%, 17.5 \%, 20 \%$ and $22.5 \%$ content by mass, prior to recompaction of the sample into PVC tube moulds for multiple tests, including falling head permeability testing. The results showed a peak reduction of $17 \%$ after 21 days of curing, taking the permeability from $7.72 \times 10^{-7}$ to $6.43 \times 10^{-7} \mathrm{~m} / \mathrm{s}$.

\subsection{MICP Using Bacillus megaterium}

The excessive ammonia and ammonium ions released during MICP has caused some researchers to examine alternatives to the hydrolysis of urea via urease. $\mathrm{Li}$ et al. [29] turned to another enzyme, asparaginase, as a means of facilitating MICP activity within a sand. The enzyme was provided by the bacterium Bacillus megaterium, delivered to the sand in a bio-grout solution. Levels of improvement to the unconfined compressive strength of the sample, and reduction to the sand's permeability matched those of identical but urease-based treatments additionally conducted for comparative purposes. Although the natural permeability of the sand sample was not detailed, the coefficient of permeability values of $2.3 \times 10^{-7}$ and $2.0 \times 10^{-7} \mathrm{~m} / \mathrm{s}$ for the asparaginase and urease treatments, respectively, were described as significant reductions. Li et al. [29] followed the measurements of the mechanical changes to the sand with scanning electron microscope-energy dispersive $\mathrm{x}$-ray spectrometer (SEM-EDS) analysis. 
Their results showed clear crystal morphologies of calcium carbonate among the sand particles, alongside rod-shaped B. megaterium cells. Samples treated with a control bio-grout that lacked bacterial cells was also examined, with no crystal morphologies present. However, in common with other MICP-based permeability reduction studies, it was noted, upon x-ray computed tomography (XCT) examination, approximately $54 \%$ of the calcite precipitation had occurred in the first $380 \mathrm{~mm}$ section of the sand sample, with approximately $40 \%$ being found in the remaining $370 \mathrm{~mm}$ section. This heterogeneous distribution pattern was explained as a result of the MICP activity favouring aerobic conditions, as well as the transportation of later bacterial cells being inhibited by early calcite precipitation in the voids.

The bacterium B. megaterium was also employed as an alternative means of MICP bacterial treatment in Soon et al. [30]. This study also departs from the main bulk of MICP soil modification literature, in that it treated not only medium-course grained sand, but also fine grained residual soil samples. The sand sample consisted of "typical concrete sand", whereas the fine-grained soil consisted of a tropical residual soil obtained from a site found on the campus compound of the Universiti Tunku Abdul Rahman, Kuala Lumpur. Both the sand and the residual soil were classified to the British Soil Classification System (BSCS). The results of the classifications were reported as a well graded SAND, and a sandy SILT with high plasticity. The maximum dry density (MDD) of the residual soil was investigated via standard Proctor compaction and found to 1.56 $\mathrm{Mg} / \mathrm{m}^{3}$. All subsequent tests conducted on the residual soil were carried out in three iterations, with samples compacted to dry densities that were $85 \%, 90 \%$ or 95\% of the MMD. Part of the engineering properties tested on both soils included an examination of the coefficient of permeability. The tests were conducted on samples that were wholly untreated, samples treated using a solution without bacterial cells containing only the reagents, and samples that were treated using a solution with bacterial cells and reagents. The results showed a clear pattern that the saturated hydraulic conductivity $\left(k_{\mathrm{sat}}\right)$ reduced in all samples treated with bacterial cells and reagents. Further, it appeared that the closer samples were to the MDD, the greater the reduction in $k_{\text {sat }}$. The correlation between calcite precipitation and $k_{\text {sat }}$ reduction is reinforced by SEM imagery taken post-test. Untreated samples were described as having relatively smooth particle surfaces, whereas samples treated with only reagents had some observed crystals on the soil particles, but samples treated with bacterial cells and reagents presented abundant calcite crystals within the soil particles. Closer observations revealed rod-shaped $B$. megaterium cells in intimate contact with precipitated calcite, indicating their role in acting as crystal nucleation sites.

\subsection{Summary}

These documented studies have shown MICP to successfully reduce the coefficient of permeability of sands by between $80 \%$ and $99 \%$, through the application of the ureolytic soil bacteria $S$. pasteurii and B. megaterium. This study therefore 
aimed to investigate if using an MICP treatment technique with $S$. pasteurii could also reduce the permeability of lateritic soil to prevent the rainwater saturation, and therefore impassability, of lateritic ENS roads. This was investigated by means of a constant head permeability test as per BS1377-6:1990 [31], using a hydraulic Rowe cell permeameter, applying the methodology of an experimental pre-treatment/post-treatment investigation.

\section{Materials and Methodology}

\subsection{Soil Material}

The Brazilian soil sample was taken from the surface of an ENS road adjoining the Brazilian highway BR626, which runs into the city of Vitoria in Espirito do Santo, Brazil. The soil description according to BS5930:2015 [32] was a very stiff yellowish brown silty CLAY with frequent quartz. Due to it being a cohesive residual tropical soil, it was classified according to BS1377-2:1990 [31] as a low plasticity clay. This was determined from the testing of its liquid limit $\left(\omega_{L}\right)$, which was $30.5 \%$, and its plastic limit $\left(\omega_{p}\right)$, which was $19.9 \%$. This gave a low plasticity index $\left(I_{p}\right)$ value of $10.6 \%$. Standard Proctor compaction testing placed the soil's $\mathrm{MDD}$ at $1.7 \mathrm{Mg} / \mathrm{m}^{3}$, and its optimum moisture content (OMC) for compaction at $16 \%$. Particle density $\left(\rho_{s}\right)$ testing using pyknometers revealed that the $\rho_{s}$ of the sample was $2.65 \mathrm{Mg} / \mathrm{m}^{3}$.

The results gathered from the standard Proctor compaction gave guidance as to how the sample should be compacted into the Rowe cell. This was in order to ensure each sample was suitably configured so as not to provide the potential for confounding variables in the data through variations in sample density.

\subsection{Ureolytic Bacterial Strain Cultivation}

A type strain of $S$. pasteurii (ATCC 11859) was acquired from the American Type Culture Collection in Virginia, USA. "Bang medium" was used to grow the bought strain of $S$. pasteurii.

The medium was created from a dry mass formulation of the following laboratory grade constituents (per litre of solute); $5 \mathrm{~g}$ ammonium sulphate, $2 \mathrm{~g}$ glutamic acid, $4.5 \mathrm{~g}$ tricine, $10 \mathrm{~g}$ tryptone, $5 \mathrm{~g}$ yeast extract and $10 \mathrm{~g}$ urea. Multiple literature sources have stated that the urea mass should be added after autoclaving to prevent thermal degradation of the urea molecules. However, during this study it was found that autoclaving the Bang medium with the urea already added did nothing to prevent the rapid growth of $S$. pasteurii in under 48 hours. Preparation in this way also helped to reduce the possibility of the contamination of the medium.

The bacterial growth was conducted in aerated flask in a Stuart SI600 orbital shaker, set to $100 \mathrm{rpm}$ at $30^{\circ} \mathrm{C}$, until bacterial growth had reached approximately $10^{7}$ cells $/ \mathrm{mL}$, determined by an $\mathrm{OD}_{600}$ value of 0.8 - 1.2. Microscope and urease indicative agar examination ascertained that the bacterial mass produced in the Bang medium was a monoculture of $S$. pasteurii. The Bang medium was then centrifuged in a Jouan CR3i centrifuge at $3000 \mathrm{rpm}$ and $30^{\circ} \mathrm{C}$ for 20 minutes. 
After centrifugation, the supernatant was carefully removed and the bacterial pellet was re-suspended in phosphate buffer solution and then centrifuged once more. The supernatant was again removed and the washed bacterial pellet was re-suspended in a $0.5 \mathrm{M}$ solution of urea in distilled water to form a soil inoculum solution. A magnetic stirrer was used to ensure the thorough mixing of the urea and bacterial cells within the inoculum.

\subsection{Soil Treatment, Compaction, Saturation and Consolidation}

Alongside the soil inoculum, a calcium chloride $\left(\mathrm{CaCl}_{2}\right)$ solution was formulated in a separate container at a molar concentration of $0.5 \mathrm{M}$. The soil inoculum was manually mixed into the dry soil material, after which the $\mathrm{CaCl}_{2}$ was also added to the soil in an identical fashion. This was in not only in order to deliver the bacteria cells and urea evenly to the soil, but also to prevent the premature precipitation of calcite crystals before compaction into the cell had been implemented.

The volume of inoculum and $\mathrm{CaCl}_{2}$ solution added remained constant for all samples, and was set in order to bring the air-dried soil's moisture content up to the OMC of $16 \%$. The wetted soil was then compacted in the hydraulic Rowe cell using the methodology found in BS1377-6:1990 3.3.6.5 [31], which employs the use of a $2.5 \mathrm{~kg}$ hammer. Each sample was compacted and levelled in order to reach a specified dry density of $1.7 \mathrm{Mg} / \mathrm{m}^{3}$. This was conducted to ensure that the soil's permeability was tested while it was in as dense a configuration as possible. Porous stone discs were fashioned top and bottom of the sample.

Once the cell was constructed and hydraulically sealed, the sample was saturated until the ratio between the change in pore water pressure and the change in applied vertical stress $(\delta u / \delta \sigma)$ of 0.9 was achieved during vertical loading increments, as per BS1377-6:1990 3.5.2.3.11 [31]. Then consolidation was implemented using one-way vertical drainage under equal strain loading, with alternating increases to the cell pressure and then back pressure being made until pore water dissipation $(U)$ had exceeded $95 \%$ as per Equation (1), according to BS1377-6:1990 3.5.4.5 [31], where $u_{1}$ is the pore pressure at the beginning of the consolidation phase, $u_{2}$ is the pore pressure at the end of the primary consolidation phase, and $u$ is the instantaneous pore pressure reading at any given point.

$$
U=\frac{u_{1}-u}{u_{1}-u_{2}} \times 100
$$

\subsection{Soil Permeability Testing}

With the sample consolidated, the drain channel hydraulic pressure was increased to the level of the back pressure, at which point the drain valve was opened. The soil's coefficient of vertical permeability $\left(k_{v}\right)$ was derived from the mean rate of flow $(q)$ of water passing through the cross-sectional area $(A)$ of the sample, along its length $(L)$, under a hydraulic gradient $(i)$. The calculation of $k_{v}$ is shown in Equation (2).

$$
k_{v}=\frac{1.63 q L}{A i}
$$


Four different applications of $i$ of 5, 10, 15 and $20 \mathrm{kPa}$ were applied to every sample. The gradients were applied in order of lowest to highest, and no gradient higher than $20 \mathrm{kPa}$ was applied. Both of these steps were undertaken in an effort to reduce the likelihood of piping manifesting in the sample, and thus undermining the validity of all of the results that would follow.

\subsection{Measurements}

The sample's volume was derived from the Rowe cell's diameter of $100 \mathrm{~mm}$ and length of $40 \mathrm{~mm}$, into which the sample was compacted and trimmed. In order to monitor how closely to the desired bulk density each sample had been compacted into the Rowe cell, the body of the cell was weighed prior to and after compaction to assess the mass of the soil sample that had been added. This allowed the bulk density of the sample to be calculated, from which the dry density was also derived, both according to the method for a cylindrical sample found in BS1377-2:1990 7.2.5 [31].

Usually, the value of $q$ in fine-grained soils is difficult to determine in the constant head permeameter when using standpipes to monitor the change in pressure head, as covered by BS1377-6:1990 [31]. This has led to the traditional use of the non-standardised falling head permeameter. However, the automatic pressure controller $(A P C)$ units that were used to supply the regulated hydraulic pressure to the Rowe cell have the ability to measure the volumetric changes of the water leaving and entering the cell to $1000^{\text {th }}$ of $\mathrm{a} \mathrm{cm}^{3}$. The change in water volume entering into the drain automatic pressure controller was recorded alongside a computer time-codex, allowing the value of $q$ to be easily determined, as per Equation (3), and thus the standardised constant head test could be employed.

$$
q=\frac{\Delta A P C_{\text {volume }}}{t}
$$

\subsection{Experimental Cells}

The permeability testing of the soil samples was split into multiple experimental cells so as to assess how soon any reductions in the coefficient of permeability were seen after the application of the MICP treatment. Three cells were devised, each having a "curing" duration for the MICP treatment of either a 24, 48 or 96-hour period. The soil samples cured in situ after being compacted into the Rowe cell body. This ensured that no disruption to the calcite crystal structures occurred once they had been precipitated. As the urease enzyme works most efficiently at $30^{\circ} \mathrm{C}$, the Rowe cell body was placed into an incubator at $30^{\circ} \mathrm{C}$ for the whole duration of the incubation periods. Samples were visually inspected to ensure no shrinkage of the soil material had compromised its compaction into the cell body.

A set of three control experimental cells were also tested, where once again three curing periods were implemented despite the lack of any MICP treatment, which were identical to the treated samples. Only distilled water was added to 
the samples to bring the soil's moisture content to $16 \%$, prior to compaction into the Rowe cell, so that the controls were as impermeable as naturally possible through being as close to the MDD value indicated by the Proctor compaction testing. The proximity of the soil to MDD reduced the ratio of voids to the theoretical minimum. In order to ensure that this "faux incubation" remained as faithful as possible to the treatment process, the Rowe cell body within which a given control sample was compacted was also placed into the incubator at $30^{\circ} \mathrm{C}$.

\section{Results}

\section{1. $k_{v}$ Values for Control Samples}

The values of $q$ and $k_{v}$ recorded for each control and MICP treated test sample are detailed in Table 1 and Table 2, respectively. The lowest $k_{v}$ value recorded during permeameter testing of controls samples was $6.99 \times 10^{-9} \mathrm{~m} / \mathrm{s}$ in the "48-hour c" sample, and the lowest average $k_{v}$ value during the application of the four values of $i$ was $3.32 \times 10^{-8} \mathrm{~m} / \mathrm{s}$ for the "96-hour a" incubated sample.

The lowest $k_{v}$ value recorded during the testing of MICP treated samples, appearing in two 24-hour incubated samples was $2.33 \times 10^{-9} \mathrm{~m} / \mathrm{s}$ and the lowest average $k_{v}$ during the application of the four values of $i$ was $6.80 \times 10^{-9} \mathrm{~m} / \mathrm{s}$ for the "24-hour c" sample.

The values of $k_{v}$, as averaged in Table 3, and represented in Figure 1 show

Table 1. Values of $q$ and $k_{v}$ for control samples.

\begin{tabular}{|c|c|c|c|c|c|c|}
\hline \multirow{2}{*}{ Control test sample } & \multirow{2}{*}{ Measured parameter } & \multicolumn{4}{|c|}{ Measured value for each $i$ tested } & \multirow{2}{*}{ Average } \\
\hline & & $5 \mathrm{kPa}$ & $10 \mathrm{kPa}$ & $15 \mathrm{kPa}$ & $20 \mathrm{kPa}$ & \\
\hline \multirow{2}{*}{ 24-hour a } & $q(\mathrm{~mL} / \mathrm{min})$ & $6.00 \times 10^{-2}$ & $2.52 \times 10^{-1}$ & $3.60 \times 10^{-1}$ & $3.66 \times 10^{-1}$ & ${ }^{1} 2.60 \times 10^{-1}$ \\
\hline & $k_{v} \quad(\mathrm{~m} / \mathrm{s})$ & $9.33 \times 10^{-8}$ & $1.96 \times 10^{-7}$ & $1.87 \times 10^{-7}$ & $1.42 \times 10^{-7}$ & $71.55 \times 10^{-7}$ \\
\hline \multirow{2}{*}{ 24-hour b } & $q(\mathrm{~mL} / \mathrm{min})$ & $3.24 \times 10^{-1}$ & $1.38 \times 10^{-1}$ & $1.20 \times 10^{-1}$ & $4.80 \times 10^{-2}$ & ${ }^{2} 1.58 \times 10^{-1}$ \\
\hline & $k_{v} \quad(\mathrm{~m} / \mathrm{s})$ & $5.04 \times 10^{-7}$ & $1.07 \times 10^{-7}$ & $6.22 \times 10^{-8}$ & $1.87 \times 10^{-8}$ & ${ }^{8} 1.73 \times 10^{-7}$ \\
\hline \multirow{2}{*}{ 24-hour c } & $q(\mathrm{~mL} / \mathrm{min})$ & $2.76 \times 10^{-1}$ & $1.32 \times 10^{-1}$ & $4.80 \times 10^{-2}$ & $5.40 \times 10^{-2}$ & ${ }^{2} 1.28 \times 10^{-1}$ \\
\hline & $k_{v} \quad(m / s)$ & $4.29 \times 10^{-7}$ & $1.03 \times 10^{-7}$ & $2.49 \times 10^{-8}$ & $2.10 \times 10^{-8}$ & ${ }^{8} 1.45 \times 10^{-7}$ \\
\hline \multirow{2}{*}{ 48-hour a } & $q(\mathrm{~mL} / \mathrm{min})$ & $1.80 \times 10^{-2}$ & $1.62 \times 10^{-1}$ & $1.08 \times 10^{-1}$ & $7.20 \times 10^{-2}$ & $29.00 \times 10^{-2}$ \\
\hline & $k_{v} \quad(\mathrm{~m} / \mathrm{s})$ & $2.80 \times 10^{-8}$ & $1.26 \times 10^{-7}$ & $5.60 \times 10^{-8}$ & $2.80 \times 10^{-8}$ & $85.95 \times 10^{-8}$ \\
\hline \multirow{2}{*}{ 48-hour b } & $q(\mathrm{~mL} / \mathrm{min})$ & $7.20 \times 10^{-2}$ & $7.20 \times 10^{-2}$ & $1.80 \times 10^{-2}$ & $4.80 \times 10^{-2}$ & $25.25 \times 10^{-2}$ \\
\hline & $k_{v}(\mathrm{~m} / \mathrm{s})$ & $1.12 \times 10^{-7}$ & $5.60 \times 10^{-8}$ & $9.33 \times 10^{-9}$ & $1.87 \times 10^{-8}$ & $84.90 \times 10^{-8}$ \\
\hline \multirow{2}{*}{48 -hour c } & $q(\mathrm{~mL} / \mathrm{min})$ & $1.20 \times 10^{-2}$ & $1.20 \times 10^{-2}$ & $3.00 \times 10^{-2}$ & $1.80 \times 10^{-2}$ & ${ }^{2} 1.80 \times 10^{-2}$ \\
\hline & $k_{v} \quad(m / s)$ & $1.87 \times 10^{-8}$ & $9.33 \times 10^{-9}$ & $1.55 \times 10^{-8}$ & $6.99 \times 10^{-9}$ & ${ }^{9} 1.26 \times 10^{-8}$ \\
\hline \multirow{2}{*}{ 96-hour a } & $q(\mathrm{~mL} / \mathrm{min})$ & $1.80 \times 10^{-2}$ & $3.60 \times 10^{-2}$ & $7.20 \times 10^{-2}$ & $1.02 \times 10^{-2}$ & ${ }^{2} 3.41 \times 10^{-2}$ \\
\hline & $k_{v} \quad(\mathrm{~m} / \mathrm{s})$ & $2.80 \times 10^{-8}$ & $2.80 \times 10^{-8}$ & $3.73 \times 10^{-8}$ & $3.96 \times 10^{-8}$ & $8.32 \times 10^{-8}$ \\
\hline \multirow{2}{*}{ 96-hour b } & $q(\mathrm{~mL} / \mathrm{min})$ & $1.74 \times 10^{-1}$ & $3.60 \times 10^{-1}$ & $8.16 \times 10^{-1}$ & $9.72 \times 10^{-1}$ & ${ }^{1} 5.81 \times 10^{-2}$ \\
\hline & $k_{v} \quad(\mathrm{~m} / \mathrm{s})$ & $2.70 \times 10^{-7}$ & $2.80 \times 10^{-7}$ & $4.23 \times 10^{-7}$ & $3.78 \times 10^{-7}$ & $73.38 \times 10^{-7}$ \\
\hline \multirow{2}{*}{96 -hour c } & $q(\mathrm{~mL} / \mathrm{min})$ & $3.60 \times 10^{-2}$ & $8.40 \times 10^{-2}$ & $1.26 \times 10^{-1}$ & $1.92 \times 10^{-1}$ & ${ }^{1} 1.10 \times 10^{-1}$ \\
\hline & $k_{v}(\mathrm{~m} / \mathrm{s})$ & $5.60 \times 10^{-8}$ & $6.53 \times 10^{-8}$ & $6.53 \times 10^{-8}$ & $7.46 \times 10^{-8}$ & ${ }^{8} 6.53 \times 10^{-8}$ \\
\hline
\end{tabular}


Table 2. Values of $q$ and $k_{v}$ for MICP treated samples.

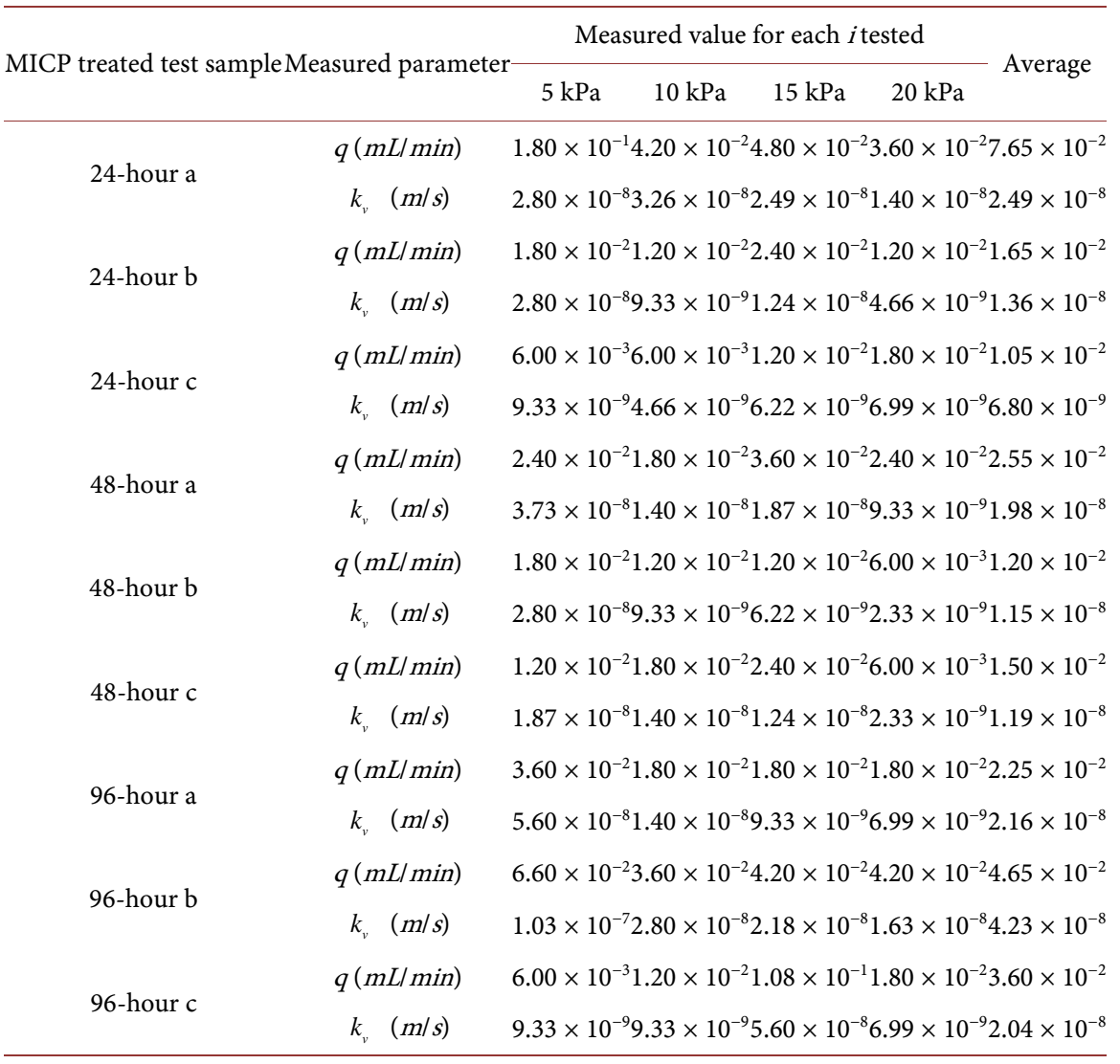

Table 3. Average $k_{v}$ values for each experimental cell.

\begin{tabular}{ccccc}
\hline \multirow{2}{*}{ Sample type } & Average $k_{v}$ for each experimental cell $(\mathrm{m} / \mathrm{s})$ & \multirow{2}{*}{ Overall average $k_{v}(\mathrm{~m} / \mathrm{s})$} \\
\cline { 2 - 4 } & 24 -hour & 48 -hour & 96 -hour & \\
\hline Control & $1.58 \times 10^{-7}$ & $4.04 \times 10^{-8}$ & $1.46 \times 10^{-7}$ & $1.15 \times 10^{-7}$ \\
MICP treated & $1.51 \times 10^{-8}$ & $1.44 \times 10^{-8}$ & $2.81 \times 10^{-8}$ & $1.92 \times 10^{-8}$ \\
\hline
\end{tabular}

no discernible pattern when comparisons are made between samples from different incubation periods for control and MICP treated samples. The overall average $k_{v}$ value for the MICP samples, when compared to the overall average $k_{v}$ value for the control samples, shows a decrease of $9.58 \times 10^{-8} \mathrm{~m} / \mathrm{s}$, representing an $83 \%$ reduction in the permeability. Comparing like-for-like incubation periods between the MICP treated and control samples, the decrease in $k_{v}$ values represents a $90 \%$ reduction for the 24 -hour, $64 \%$ reduction for the 48 -hour, and $81 \%$ reduction for the 96 -hour incubation periods.

The sample preparation methodology was designed to minimise the effects of the initial soil configuration on the permeability measured during the test. In order to give confidence that the density of the compacted samples had been sufficiently controlled, the $\rho_{d}$ of all control and MCP treated samples was monitored during testing. Figure 2 graphically represents the $k_{v}$ of both control and MICP treated samples alongside the recorded $\rho_{d}$, the consistency of 


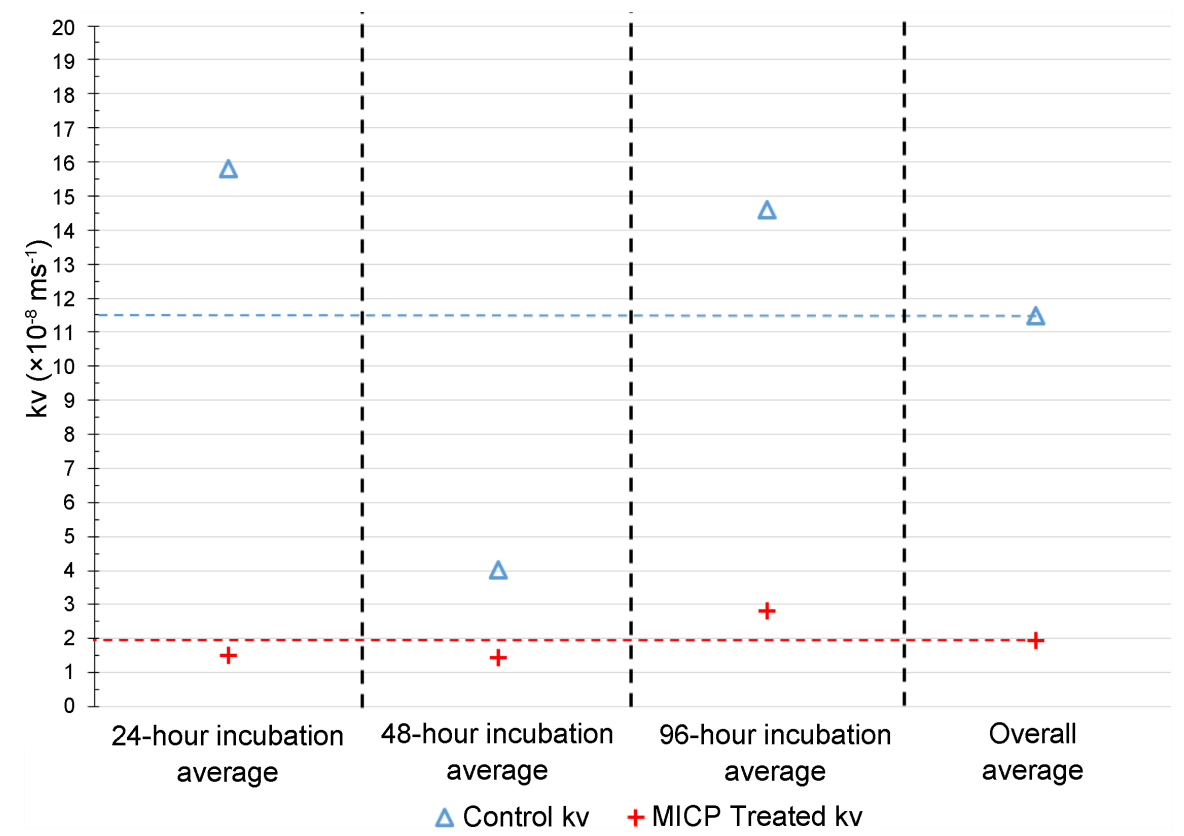

Figure 1. Average values of $k_{v}$ for each experimental cell.

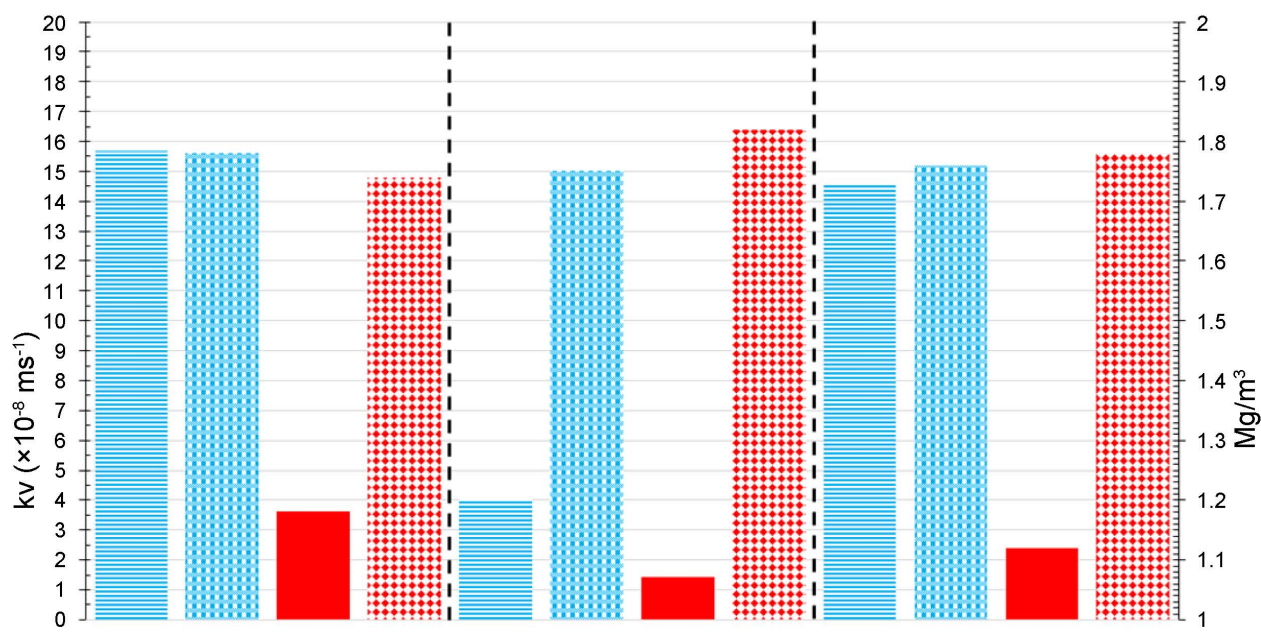

24-hour incubated samples 48-hour incubated samples 96-hour incubated samples

$$
\begin{array}{ll}
\equiv \text { Control kv } & \text { MICP Treated kv } \\
& =\text { Control od }
\end{array}
$$

Figure 2. Average values of $k_{v}$ and $\rho_{d}$ for each experimental cell.

the latter demonstrating that the changes in observed $k_{v}$ values has no correlation with the degree of sample compaction during test conditions.

\subsection{Statistical Analysis of $\boldsymbol{k}_{\mathrm{v}}$ Values}

The non-parametric Kruskal-Wallis test [33] was used to analyse the statistical significance of the results, as detailed in Equation (4). It was used to confirm that the variation in control sample $k_{v}$ values was statistically insignificant, while the variation of $k_{v}$ values between the control and treated samples had a statistical significance. 
The Kruskal-Wallis test is a non-parametric alternative to the ANOVA test, which was able to perform a hypothesis test ( $H$ test) by ranking the nonnormally distributed $k_{v}$ data. Large values of $H$ (above 5.991) indicated that the null hypothesis (i.e. no statistical significance in the variation of $k_{v}$ value within the dataset) should be rejected. Equation (3) details the computed variables; the number of computed and ranked data points $(n)$, the sum of the data ranks contained within each group $(r)$, and the number of data groups under consideration $(n i)$.

Equation (5) shows the computation for the control samples, only. The produced $H$ value of 2.972 indicates that the variation of data within the control samples has no statistical significance. Equation (6) shows that when the $k_{v}$ values of the treated samples was added and ranked alongside to the $k_{v}$ values of the control samples, the $H$ value of 60.65 indicates there is then a statistically significant variation within the dataset, which can only be explained as the difference between control and treated $k_{v}$ values.

$$
\begin{gathered}
H=\frac{12}{n(n+1)} \sum\left(\frac{r^{2}}{n i}\right)-n i(n+1) \\
H=\frac{12}{9(10)} \sum\left(\frac{9^{2}}{3}+\frac{22^{2}}{3}+\frac{14^{2}}{3}\right)-3(10) \\
H=\frac{12}{18(19)} \sum\left(\frac{50^{2}}{3}+\frac{72^{2}}{3}+\frac{49^{2}}{3}\right)-3(19)
\end{gathered}
$$

\section{Discussion}

\section{1. $k_{\mathrm{v}}$ Results}

The average $k_{v}$ value of $1.15 \times 10^{-7} \mathrm{~m} / \mathrm{s}$ for the control samples shows that the soil can already be considered a low permeability soil, falling just under the $k$ value expected for silty clays (ML-CL) of $>2.5 \times 10^{-7} \mathrm{~m} / \mathrm{s}$ [34]. This is consistent with the soil description given in Section 2.1. Following the MICP treatment regime, the average $k_{v}$ value measured has fallen to $1.92 \times 10^{-8} \mathrm{~m} / \mathrm{s}$, an $83 \% \mathrm{re}$ duction that is comparable to the $80 \%$ or greater reduction in permeability achieved by the studies listed in Section 1. This means that the treatment has changed the permeability value of the soil from a silty clay, to that of a low-plasticity clay at $>5 \times 10^{-8} \mathrm{~m} / \mathrm{s}$.

Assessment of Figure 1, coupled with the fact that all samples were saturated when subjected to permeability testing, no obvious discrepancies existed between the soil sample configurations (e.g. density, moisture content, etc.), other than that caused by the application of MICP treatment bacterial cells and reagents. Temporally, no obvious minimum effective curing period was present in the results, with at least one sample from the 24, 48 and 96-hour incubation periods possessing a $k_{v}$ value under $1.00 \times 10^{-8} \mathrm{~m} / \mathrm{s}$.

\subsection{Significance of Results and Further Research}

The statistical analysis applied to both the control group, and then the control 
and treated group combined, further reinforces that there was only a significant change in $k_{v}$ values when the soil was treated using $S$. pasteurii in conjunction with the MICP chemical reagents urea and $\mathrm{CaCl}_{2}$. This is confirmed by the $H$ value of 60.65 that was derived from the Kruskal-Wallis analysis of the combined and ranked control and MICP treated experimental cells dataset.

However, the testing regime used in this study has only shown that treating a soil with the bacterial cells and reagents of MICP has reduced the permeability of the lateritic soil, not that MICP itself was the mechanism directly responsible. This would require detailed examination, perhaps using SEM or Atomic Force Microscopy (AFM), to confirm. The observed reduction in the soil's permeability may have been as a result of "bioclogging". This is simply where the introduction of bacterial cells into the soil voids causes the development of insoluble biomass in the pore throats, which impedes the flow of water through the soil. The MICP bacterium, $S$. pasteurii, is a ubiquitous soil bacterium that is very adept at creating a biofilm, which it uses to anchor the bacterial colony to soil particles. A build-up of biofilm biomass in the soil pore throats should therefore be an expected feature, but to what degree this happens has not been studied in lateritic soils.

Whether calcite precipitation or bioclogging actually provides the mechanism, it can be concluded that the permeability of a lateriticsoil can be reduced to a statistically significant degree using the bacterium $S$. pasteurii and the reagents associated with MICP. As this outcome may be beneficial to supporting the economic advancement of rural communities in the developing world, it therefore warrants further investigation into whether the observed reduction in permeability was related to calcite precipitation or bioclogging, so as to ascertain:

- If biomass aggregation is responsible, does $S$. pasteurii provide a degree of permeability reduction less than, or greater than, as well as more sustainable than currently utilised bioclogging bacteria and media?

- If calcite crystals deposited by MICP activity is indeed responsible, does depositing calcite crystals outstrip the permeability reducing performance of other biological agents, or present a more efficient or sustainable alternative?

\subsection{Potential Impact of Results}

If the ability of MICP to reduce the permeability of lateritic soil can be refined and up-scaled, it will provide geotechnical engineers with a new soil modification agent with which to combat rural ENS road closures. This may take the form of a soil inoculum solution, produced at a local bio-chemical production facility. The solution could be transported to a rural ENS road site in a mobile incubation tank. Ideally, this incubation tank could be trailed behind a highways construction vehicle, where a spray-based delivery system would add the soil inoculum solution to the ENS road soil surface layer. This layer would more than likely need to be disturbed first by highway operatives, so as to allow the sprayed inoculum to penetrate the soil to a reasonable degree. The operatives would then immediately re-compact and shape the ENS road surface and allow the material 
to cure.

Development of a technique similar to the above will provide a low-cost, low tech and sustainable method by which nations within the developing world can ensure their village clusters are no longer cut-off from mechanised transport for long periods of time. This will mean that the rural road networks may be able to fulfil their purpose, as originally envisaged, of providing rural populations with the infrastructure they need to help raise themselves out of their current impoverished condition.

\section{Conclusions}

The results of the Rowe cell permeability testing undertaken by this study indicates that the coefficient of permeability of a lateritic soil sample was successfully reduced from an average of $1.15 \times 10^{-7} \mathrm{~m} / \mathrm{s}$ for untreated control samples, to $1.92 \times 10^{-8} \mathrm{~m} / \mathrm{s}$ in samples that were treated using MICP reagents and $S$. pasteurii bacterial cells. This represents an $83 \%$ reduction in permeability.

In this study, no attempt has been made to determine the exact mechanism responsible for the reduction in soil permeability, but the aggregation of mass associated with the addition of $S$. pasteurii and MICP reagents to the soil has been shown to be responsible for the statistically significant lowering of permeability values.

Whether this mass is indeed the precipitation of calcite crystals, or simply just some biomass aggregation due to the affinity of $S$. pasteurii for producing anchoring biofilms, was not clarified in this study. Therefore, further research will need to be undertaken (e.g. repeating Rowe cell permeability testing in conjunction with SEM or AFM imagery) to clarify if the hypothesis presented by this study is demonstrable, and as to what the actual material nature of such accumulations happens to be.

\section{Acknowledgements}

The authors wish to express their gratitude to the Technical Support staff of both the Biomedical Sciences laboratory, Portland Building and the Material Testing Laboratory, Northern Terrace at Leeds Beckett University for their continual support, expert advice, and above all, patience.

\section{References}

[1] Bryceson, D.F., Bradbury, A. and Bradbury, T. (2008) Roads to Poverty Reduction? Exploring Rural Roads' Impact on Mobility in Africa and Asia. Development Policy Review, 26, 459-482. https://doi.org/10.1111/j.1467-7679.2008.00418.x

[2] Roberts, P., Shyam, K.C. and Rastogi, C. (2006) Rural Access Index: A Key Development Indicator. Transport Papers TP-10 March 2006, The World Bank Group, Washington DC. http://hdl.handle.net/10986/17414

[3] Faiz, A. (2012) The Promise of Rural Roads: Review of the Role of Low-Volume Roads in Rural Connectivity, Poverty Reduction, Crisis Management, and Liveability. Transportation Research Circular, No. E-C167. https://doi.org/10.17226/22711

[4] Cook, J.R., Petts, R.C. and Rolt, J. (2013) Low Volume Rural Road Surfacing and 
Pavements: A Guide to Good Practice. OTB Engineering UK LLP, London.

[5] Gwiyani-Nkhoma, B. (2011) Irrigation Development and Its Socioeconomic Impact on Rural Communities in Malawi. Development Southern Africa, 28, 209-223. https://doi.org/10.1080/0376835X.2011.570068

[6] Paton, T.R. and Williams, M.A.J. (1972) The Concept of Laterite. Annals of the Association of American Geographers, 61, 45-56. https://doi.org/10.1111/j.1467-8306.1972.tb00842.x

[7] Buchanan, F. (1807) A Journey From Madras through the Countries of Mysore, Canara and Malabar. 2nd Edition, East Indian Company, London, 436-560.

[8] Ugbe, F.C. (2011) Effect of Multicyclic Compaction on Cohesion in Lateritic Soils. Archives of Applied Science Research, 3, 115-121.

[9] Singh, T.B., Patra, S.K. and Devi, K.N. (2013) Study on Sesquioxide Content and Lime Requirement of Lateritic Soils. International Journal of Bio-Resource and Stress Management, 4, 518-522.

[10] Smith, I. (2006) Smith's Elements of Soil Mechanics. 8th Edition, Blackwell Publishing, Oxford.

[11] Kamtchueng, B.T., Onana, V.L., Fantong, W.Y., Ueda, A., Ntouala, R.F.D., Wongolo, M.H.D., Ndongo, G.B., Ngo'o Ze, A., Kamgang, V.K.B. and Ondoa, J.M. (2015) Geotechnical, Chemical and Mineralogical Evaluation of Lateritic Soils in Humid Tropical Area (Mfou, Central-Cameroon): Implications for Road Construction. International Journal of Geo-Engineering, 6, 1.

[12] Gwilliam, K., Foster, V., Archondo-Callao, R., Briceño-Garmendia, C., Nogales, A. and Sethi, K. (2008) Africa Infrastructure Country Diagnostic: Roads in SubSaharan Africa. Summary of Background Paper, No. 14.

http://documents.worldbank.org/curated/en/938171468194345853/Africa-infrastruc ture-country-diagnostic-roads-in-Sub-Saharan-Africa

[13] Hine, J. and Rutter, J. (2000) Roads, Personal Mobility \& Poverty: The Challenge. Transport Research Laboratory, World Bank, Washington DC.

[14] Ngongondo, C., Xu, C., Gottschalk, L. and Alemaw, B. (2011) Evaluation of Spatial and Temporal Characteristics of Rainfall in Malawi: A Case of Data Scare Region. Theoretical and Applied Climatology, 106, 79-93. https://doi.org/10.1007/s00704-011-0413-0

[15] Chinowsky, P.S., Schweikert, A.E., Strzepek, N.L. and Strzepek, K. (2015) Infrastructure and Climate Change: A Study of Impacts and Adaptions in Malawi, Mozambique, and Zambia. Climate Change, 130, 49-62. https://doi.org/10.1007/s10584-014-1219-8

[16] Chinowsky, P.S., Schweikert, A.E., Strzepek, N.L. and Strzepek, K. (2015) Road Infrastructure and Climate Change in Vietnam, Sustainability, 7, 5452-5470. https://doi.org/10.3390/su7055452

[17] Ivanov, V. and Chu, J. (2008) Applications of Microorganisms to Geotechnical Engineering for Bioclogging and Biocementation of Soil in Situ. Reviews in Environmental Science and Bio/ Technology, 7, 139-153. https://doi.org/10.1007/s11157-007-9126-3

[18] DeJong, J.T., Fritzges, M.B. and Nüsslein, K. (2006) Microbially Induced Cementation to Control Sand Response to Undrained Shear. Journal of Geotechnical and Geoenvironmental Engineering, 132, 1381-1392. https://doi.org/10.1061/(ASCE)1090-0241(2006)132:11(1381)

[19] Al Qabany, A., Soga, K. and Santamarina, C. (2012) Factors Affecting Efficiency of Microbially Induced Calcite Precipitation. Journal of Geotechnical and Geoenvi- 
ronmental Engineering, 138, 992-1001. https://doi.org/10.1061/(ASCE)GT.1943-5606.0000666

[20] Yoon, J.-H., Lee, K.-C., Weiss, N., Kho, Y.H., Kang, K.H. and Park, Y.-H. (2001) Sporosarcina aquimarina sp. Nov., a Bacterium Isolated from Seawater in Korea, and Transfer of Bacillus globisporus (Larkin and Stokes 1967), Bacillus psychrophilus (Nakamura 1984) and Bacillus pasteurii (Chester 1898) to Genus Sporosarcina as Sporosarcina globispora comb. nov., Sporosarcina psychrophilus comb. nov., and Sporosarcina pasteurii comb. nov., and Emended Description of the Genus Sporosarcina. International Journal of Systematic and Evolutionary Microbiology, 51, 1079-1086. https://doi.org/10.1099/00207713-51-3-1079

[21] Soon, N.W., Lee, M.L. and Hii, S.L. (2012) An Overview of the Factors Affecting Microbial-Induced Calcite Precipitation and Its Potential Application in Soil Improvement. World Academy of Science, Engineering and Technology, 62, 723-729. http://researchrepository.murdoch.edu.au/id/eprint/399

[22] Whiffin, V. (2004) Microbial $\mathrm{CaCO}_{3}$ Precipitation for the Production of Biocement. PhD Thesis, Murdoch University, Perth.

[23] Douglas, S. and Beveridge, T.J. (1998) Mineral Formation by Bacteria in Natural Microbial Communities. FEMS Microbiology Ecology, 26, 79-88. https://doi.org/10.1111/j.1574-6941.1998.tb00494.x

[24] Whiffin, V., van Paassen, L.A. and Harkes, M.P. (2007) Microbial Carbonate Precipitation as a Soil Improvement Technique. Geomicrobiology Journal, 24, 417-423. https://doi.org/10.1080/01490450701436505

[25] Stabnikov, V., Naeimi, M., Ivanov, V. and Chu, J. (2011) Formation of Water-Impermeable Crust on Sand Surface Using Biocement. Cement and Concrete Research, 41, 1143-1149.

[26] Chu, J., Stabnikov, V. and Ivanov, V. (2012) Microbially Induced Calcium Carbonate Precipitation on Surface or in the Bulk of Soil. Geomicrobiology Journal, 29, 544-549. https://doi.org/10.1080/01490451.2011.592929

[27] West, T.R. (2010) Geology Applied to Engineering. Reissue Edition, Waveland Press Incorporated, Illinois.

[28] Omar, R.C., Roslan, R., Baharuddin, I.N.Z. and Hanafiah, M.I.M. (2016) Micaceous Soil Strength and Permeability Improvement Induced by Microbacteria from Vegetable Waste. International Engineering Research and Innovation Symposium (IOP Conference Series: Materials Science and Engineering), 160, 1-9.

[29] Li, M., Fu, Q.L., Zhang, Q., Achal, V. and Kawasaki, S. (2015) Bio-Grout Based on Microbially Induced Sand Solidification by Means of Asparaginase Activity. Scientific Reports, 5, 16128. https://doi.org/10.1038/srep16128

[30] Soon, N.W., Lee, M.L., Khun, T.C. and Ling, H.S. (2013) Improvements in Engineering Properties of Soils through Microbial-Induced Calcite Precipitation. KSCE Journal of Civil Engineering, 17, 718-728. https://doi.org/10.1007/s12205-013-0149-8

[31] BSI (1990) BS 1377: 1990-Methods of Test for Soils for Civil Engineering Purposes. British Standards Institute, Milton Keynes.

[32] BSI (2015) BS 5930: 2015-The Code of Practice for Site Investigations. British Standards Institute, Milton Keynes.

[33] Kruskal, W.H. and Wallis, W.A. (1952) Use of Ranks in One-Criterion Variance Analysis. Journal of the American Statistical Association, 47, 583-621. https://doi.org/10.1080/01621459.1952.10483441

[34] Lindeburg, M.R. (2015) Civil Engineering Reference Manual for the PE Exam. 15th Edition, Professional Publications Inc., Balmont. 
Submit or recommend next manuscript to SCIRP and we will provide best service for you:

Accepting pre-submission inquiries through Email, Facebook, LinkedIn, Twitter, etc. A wide selection of journals (inclusive of 9 subjects, more than 200 journals)

Providing 24-hour high-quality service

User-friendly online submission system

Fair and swift peer-review system

Efficient typesetting and proofreading procedure

Display of the result of downloads and visits, as well as the number of cited articles Maximum dissemination of your research work

Submit your manuscript at: http://papersubmission.scirp.org/

Or contact nr@scirp.org 